\title{
A note on the determination of serum beta-glucuronidase activity
}

\author{
CONSTANCE H. J. PLAICE \\ From the Department of Pathology, Southmead General Hospital, Westbury on Trym, Bristol
}

SYNOPSIS A modification of the method of Fishman, Springer, and Brunetti (1948) for determining serum $\beta$-glucuronidase activity is described. Normal values are presented and some of the factors which might influence the serum enzyme determination have been investigated.

The concentration of the enzyme $\beta$-glucuronidase in blood has been of interest in the study of various types of cancer and other diseases (McDonald and Odell, 1947; Cohen and Huseby, 1951; Fishman, Kasdon, Bonner, Fishman, and Homburger, 1951; Follette, Valentine, and Lawrence, 1952; Hackensellner, Seelich, and Lind, 1958; Ohkubo, Sonoda, and Kusunoki, 1958; Mattea, Pietra, and Viola, 1959; Goldbarg, Pineda, Banks, and Rutenburg, 1959; Pineda, Goldbarg, Banks, and Rutenburg, 1959; Whitaker, 1960). The methods most commonly used for the determination of the enzyme level are those of Talalay, Fishman, and Huggins (1946), where the enzyme acting upon phenolphthalein mono- $\beta$-glucuronic acid liberates phenolphthalein which is estimated colorimetrically, and of Fishman, Springer, and Brunetti (1948) using the same substrate but protein being removed by precipitation with trichloroacetic acid. While using the latter method it was noted that the final $p \mathrm{H}$ was not satisfactorily adjusted to the optimum value and that errors arose because of adsorption of phenolphthalein on the protein precipitate. The following is an account of the modifications introduced to overcome these difficulties.

\section{MODIFIED METHODS}

ADJUSTMENT OF INITIAL $p$ H Fishman et al. (1948) used an acetate buffer, $p \mathrm{H} 4 \cdot 5,0 \cdot 1 \mathrm{M}$ concentration, but it was found preferable to use twice the strength $(0 \cdot 2 \mathrm{M}, \mathrm{pH} 4 \cdot 5)$ to ensure that the $p H$ was adequately adjusted for the incubation period.

FINAL $p_{\mathrm{H}}$ At the end of incubation when the alkaline solution is added, the $p \mathrm{H}$ should be adjusted to between 10.2 and 10.5 for maximum stable colour development. In experiments using the alkaline reagent of Fishman et al. (1948), it was found that in some instances the $p \mathrm{H}$ was

Received for publication 10 March 1961.
$9 \cdot 8$ (even although in these particular experiments $0 \cdot 1 \mathrm{M}$ ( $p \mathrm{H} 4 \cdot 5$ ) acetate buffer was used for the incubation mixture). A carbonate solution $p H \quad 10.5$ (similar to that described by Abul-Fadl, 1957) was substituted for the alkaline reagent, and this gave a satisfactory final $p \mathrm{H}$.

LOSS OF PHENOLPHTHALEIN BY PROTEIN PRECIPITATION In recovery experiments where known amounts of phenolphthalein were added to serum and then estimated after the method of Fishman et al. (1948) had been carried out, considerable loss of the dye was demonstrated (Table I).

\section{TABLE I}

RECOVERY OF ADDED PHENOLPHTHALEIN (Fishman et al. (1948) method)

Phenolphthalein Added to Serum ( $\mu \mathrm{g} . / \mathrm{ml}$. Final Concentration)

$\%$ Recovery

\begin{tabular}{rl}
\hline 5 & 21 \\
5 & 30 \\
10 & 27 \\
15 & 40
\end{tabular}

Experiments were made to see what errors were caused by the presence of unprecipitated protein in the final solution. Table II demonstrated that the proportion of phenolphthalein detected varied considerably according to the amount added.

TABLE II

RECOVERY OF ADDED PHENOLPHTHALEIN IN SOLUTIONS STILL CONTAINING SERUM PROTEIN

\begin{tabular}{lcc} 
Serum & $\begin{array}{l}\text { Phenolphthalein } \\
\text { Added }(\mu \mathrm{g})\end{array}$ & $\begin{array}{c}\text { \% Phenolphthalein Detected } \\
\text { in Final Protein-containing } \\
\text { Solution }\end{array}$ \\
\hline a & 1 & 60 \\
a & 2 & 55 \\
b & 4 & 86 \\
c & 5 & 96 \\
d & 6 & 92 \\
c & 10 & 95
\end{tabular}

In addition, in many sera, there were turbid final solutions and it was therefore decided that for this reason 
and because of the protein binding of the dye, nonprecipitation of the protein was unsatisfactory.

The method finally evolved was to coagulate the protein by heat and, after cooling, add the carbonate solution directly to this solution. Fishman et al. (1948) used heat precipitation when investigating the $\beta$-glucuronidase activity in vaginal fluid but afterwards spun down the precipitate and added alkaline reagent only to the decanted supernatant solution. By adding the carbonate solution directly to the heat-coagulated solution the phenolphthalein was almost completely recovered (Table III). A small proportion of the total protein remained uncoagulated but was not sufficient to interfere with the phenolphthalein colour development.

\section{TABLE III}

RECOVERY OF ADDED PHENOLPHTHALEIN AFTER HEAT COAGULATION

ug. Phenolphthalein Added/ml. Final Solution

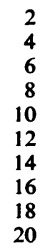

KINETICS OF SERUM $\beta$-GLUCURONIDASE

To determine the most suitable conditions for estimating the enzyme, kinetic experiments were carried out with several different, unpurified sera.

pH OPTIMUM All serum values using phenolphthalein mono- $\beta$-glucuronic acid as substrate reported in the literature have been determined at $p \mathrm{H} 4.5$, hut when a $p \mathrm{H}$ optimum curve was attempted using the heat coagulation method, at certain $p \mathrm{H}$ levels there was no or incomplete precipitation and the final solutions were turbid. Table IV indicates the errors which arose by coagulation at different $p \mathrm{H}$ levels.

\section{TABLE IV}

RECOVERY OF ADDED PHENOLPHTHALEIN AFTER COAGULATION OF SERUM PROTEIN AT DIFFERENT $p H$ LEVELS

\begin{tabular}{cc}
$p \mathrm{H}$ & $\begin{array}{c}\text { \% Recovery of Added Phenolphthalein } \\
\text { (Mean of Triplicate Values) }\end{array}$ \\
\hline 3.8 & 86 \\
4.2 & 108 \\
4.5 & 95 \\
5.0 & 102 \\
5.4 & 116
\end{tabular}

Other means of precipitation were tried, e.g., by adding an equal volume of acetone after incubation (Goldstein, 1961). With this concentration of acetone at $p \mathrm{H} 4.5$ the supernatant solutions were clear, although there was some difficulty with air bubbles due to the acetone/aqueous mixture. Furthermore, the presence of acetone depressed the phenolphthalein colour to about $30 \%$ of that in wholly aqueous solution. When this method was used to study the effect of $p \mathrm{H}$ upon the enzyme activity it was found that, as in the heat coagulation method, difficulties due to turbidity were encountered at the lower $p \mathrm{H}$ levels ( $p \mathrm{H} \mathrm{3.6}$ to $4 \cdot 0)$. A compromise was reached in that several $p \mathrm{H}$ curves were obtained from sera which had previously been shown to have a very slight, or no, turbidity when the protein was not precipitated from the final solution. Also, the protein error was reduced in one case by using serum from a woman 32 weeks pregnant and diluting the highly coloured final solutions with carbonate solution before reading the absorption values. Fig. 1 demonstrates that the $p \mathrm{H}$ curve in the range 3.6 to 5.6 (in acetate buffer) was substantially similar in the
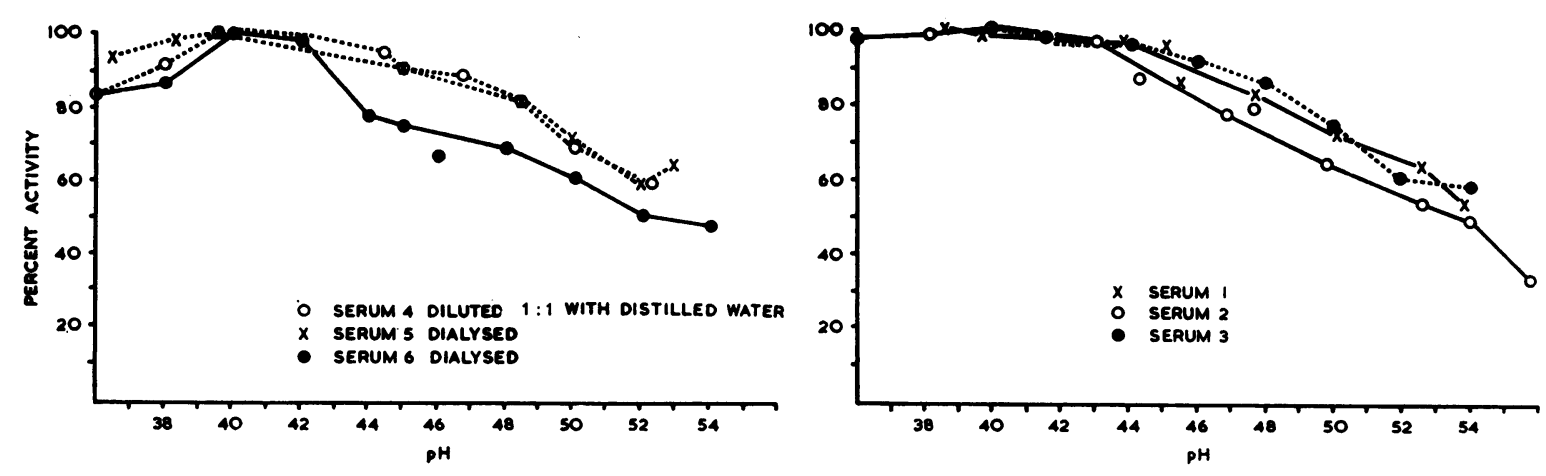

FIG. 1. Effect of $\mathrm{pH}$ of the acetate buffer upon serum $\beta$-glucuronidase activity. 
various sera and also in dialysed and diluted sera. The curve was flat and in most cases the optimum activity occurred at $p \mathrm{H} 3.9$ to 4.0 . The activity at $p \mathrm{H} 4.5$ was at least $80 \%$ of the maximum and so $p \mathrm{H} 4.5$ buffer was used in this work.

EFFECT OF DURATION OF INCUBATION The initial velocity was not investigated because of the small quantity of phenolphthalein liberated in less than three hours. Over the range three to 24 hours the amount of phenolphthalein liberated was linear in the sera investigated.

EFFECT OF SUBSTRATE CONCENTRATION AND THE $\mathrm{K}_{\mathrm{m}}$ The rate of hydrolysis in $0.2 \mathrm{M}$ acetate buffer $(p \mathrm{H} \mathrm{4.5)}$ increased with increasing substrate concentration over the range 0.25 to $4.0 \mathrm{mM}$. It was inhibited at higher substrate concentrations. For five different sera the $\mathbf{K}_{\mathbf{m}}$ for phenolphthalein mono- $\beta$-glucuronic acid, derived by the method of Lineweaver and Burk (1934), ranged from 1.0 to $2.5 \mathrm{mM}$. The different magnitude of the $K_{m}$ in different unpurified sera is due to the varying concentrations of substances which influence the enzyme, either inhibitors or activators. In four of the five sera investigated, the $K_{m}$ was between 2.0 and $2.5 \mathrm{mM}$. The optimum substrate concentration is theoretically between 4.0 and $5.0 \mathrm{mM}$. In fact, substrate was inhibited above $4.0 \mathrm{mM}$ in all the sera.

The cost of phenolphthalein mono- $\beta$-glucuronic acid is high when obtained commercially and to produce the substance biosynthetically by administering phenolphthalein to rabbits and extracting the glucuronide from the urine is not possible for most hospital biochemical laboratories. Because these considerations were pertinent in the investigation the substrate concentration used was $1.0 \mathrm{mM}$.

\section{METHOD}

About $5 \mathrm{ml}$. venous blood was taken, allowed to clot, and the serum taken off as soon as possible. The serum was again centifuged in a conical tube to ensure that all cells were removed. Care was taken not to include results from any sample which appeared to the eye to be even slightly haemolysed so that the integrity of the white cells could be assumed in the samples estimated.

Quadruplicate stoppered tubes containing $1.6 \mathrm{ml}$. $0.2 \mathrm{M}$ acetate buffer $p \mathrm{H} 4.5(11.57 \mathrm{~g}$. sodium acetate $\left(\mathrm{CH}_{3} \mathrm{COONa} \cdot 3 \mathrm{H}_{2} \mathrm{O}\right)$ and $6.5 \mathrm{ml}$. glacial acetic acid to make up to 1 litre), $0.2 \mathrm{ml}$. serum, $0 \cdot 2 \mathrm{ml} .0 .01 \mathrm{M}$ phenolphthalein mono- $\beta$-glucuronic acid (Sigma) $(510 \cdot 6 \mathrm{mg}$./ $100 \mathrm{ml}$.) in $10 \%$ ethanol were incubated at $37^{\circ} \mathrm{C}$. for 18 hours. A blank tube containing the acetate buffer and the serum was also incubated. After 18 hours $0.2 \mathrm{ml}$. substrate was added to the blank, the tubes were placed in a boiling water bath for five minutes and then cooled in a cold water bath and $2.5 \mathrm{ml}$. sodium carbonate solution
pH $10.5\left(80\right.$ g. $\mathrm{NaHCO}_{3}$ and $150 \mathrm{ml} .20 \% \mathrm{NaOH}$ made up to 1 litre, the $p \mathrm{H}$ finally adjusted with $\mathrm{NaOH}$ using a $p \mathrm{H}$ meter) was added to each tube. The coagulum and carbonate solution were carefully mixed by using a narrow glass rod, care being taken not to deposit small pieces of flocculent material on the sides of the tube above the level of the liquid. The solutions were allowed to stand for 10 minutes and then were spun for 10 minutes at 2,500 r.p.m. The supernatant solutions were decanted and read against the blank on a Uvispek spectrophotometer at $550 \mathrm{~m} \mu$. The activity was expressed in Fishman units, 1 unit being that which liberates $1 \mu \mathrm{g}$. phenolphthalein from $1 \mathrm{mM}$. substrate per hour at $37^{\circ} \mathrm{C}$. For comparative purposes the results from normal subjects were also expressed in a standard unit where one unit is that amount of enzyme which will catalyse the liberation of $1 \mu \mathrm{M}$. phenolphthalein per minute per litre of serum.

REPRODUCIBILITY Results from aliquot quantities of serum were usually in agreement within $\pm 5 \%$. Occasionally the differences were greater. There are two main factors which probably contribute to a larger error. Although care is taken to separate completely the cells from the serum it is possible that the incubation solution may at times contain one or more white cells. Another source of error is the possible contamination of the supernatant solution as it is decanted over any protein precipitate which may be adhering to the inside of the test tube above the surface of the solution. This error can be minimized by correct use of the narrow glass rod in mixing the carbonate solution and the protein precipitate.

TECHNICAL FACTORS Samples of cell-free serum could be stored for up to two months at $-20^{\circ} \mathrm{C}$. or for up to 10 days at $4^{\circ} \mathrm{C}$. with a change of activity within $\pm 10 \%$. During the enzyme assay, after coagulation of the proteins, the solution can be left for at least three hours before the carbonate solution is added, without loss of colour intensity. When the alkali is added the colour extraction is complete within 10 minutes and the supernatant should be separated within one hour to prevent errors due to the action of the carbonate solution upon the protein precipitate causing turbidity. The phenolphthalein colour is stable for two hours.

\section{RESULTS}

NoRmal Values Table $\mathrm{V}$ indicates the range of values obtained from 20 men (16 to 60 years) and 21 women ( 22 to 58 years). The blood was obtained chiefly from people working in various departments of the hospital and also from seven male in-patients before operation such as meniscectomy or herniorrhapy. The mean value for men $(680$ units $/ 100 \mathrm{ml}$. serum or 356 standard units) was $62 \%$ greater than the mean value for women $(418$ units $/ 100 \mathrm{ml}$. serum or 219 standard units). Cohen and Huseby (1951) and Goldbarg et al. (1959) noted similar differences. 
TABLE V

SERUM $\beta$-GLUCURONIDASE LEVELS IN HEALTHY INDIVIDUALS

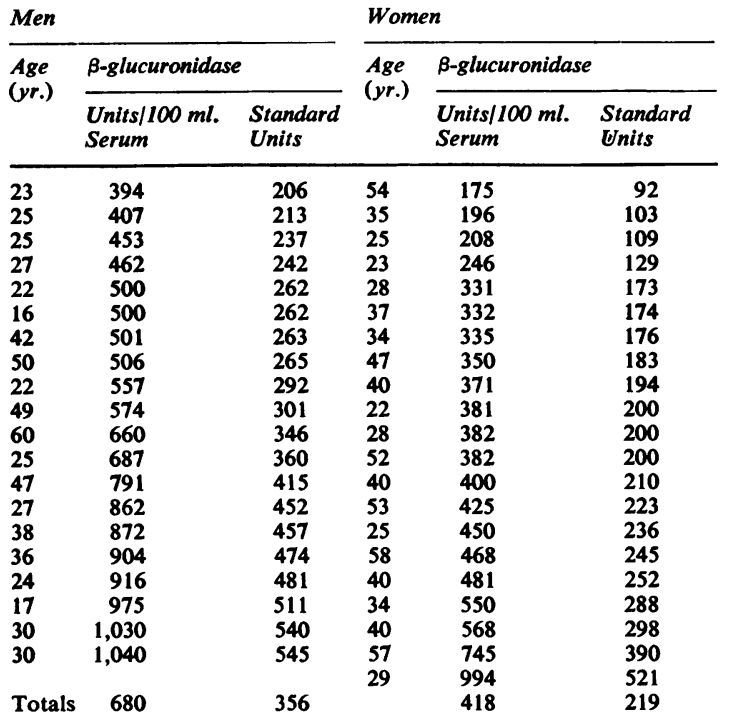

There appeared to be no correlation of enzyme activity with age.

VARIATION DURING THE DAY When blood was taken at intervals during 24 hours the variation in one man and one woman was equivalent to an S.D. of $7 \%$ and $4.2 \%$ of the mean value (Fig. 2 ). In another woman blood was taken four times in nine hours and the S.D. of the values was $9 \%$ of the mean. In another two patients fasting blood was taken at $8 \mathrm{a} . \mathrm{m}$. and another sample at noon and the differences

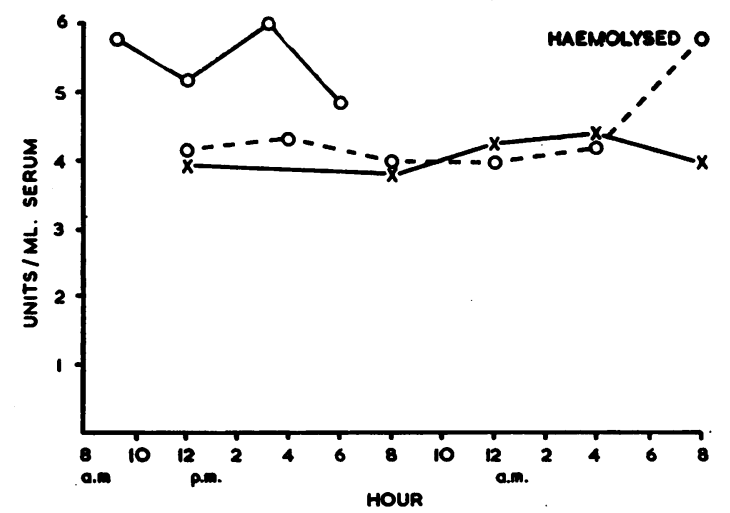

FIG. 2. Serum $\beta$-glucuronidase activity at intervals throughout one day. between the first and second samples were $3 \%$ in one patient and $1 \%$ in the other.

INFLUENCE OF THE MENSTRUAL CYCLE Blood was taken at intervals from four women (age 23 to 40 years) with normal menstrual cycles. The days of the cycle investigated were usually one, five, ovulation day (determined by the rise in waking temperature) 20 and 26 , but this timing could not be strictly adhered to. Table VI demonstrates that the greatest variation in the serum $\beta$-glucuronidase was in a woman with a standard deviation of $23 \%$ of the mean value; in two individuals the standard deviations of the mean were $14 \%$ and $17 \%$, and in the

TABLE VI

SERUM $\beta$-GLUCURONIDASE ACTIVITY DURING MENSTRUAL CYCLE

Units/100 ml. Serum

\begin{tabular}{llll}
\hline$a^{2}$ & $b$ & $c$ & $d^{1}$ \\
344 & 250 & 162 & 382 \\
$(1)^{2}$ & $(2)$ & $(1)$ & $(1)$ \\
364 & 187 & 169 & 362 \\
$(5)$ & $(5)$ & $(5)$ & $(5)$ \\
306 & 258 & 200 & 366 \\
$($ Ov $)$ & $(O v+1)$ & $(O v+1)$ & $(O v-1)$ \\
325 & 250 & 244 & 375 \\
$(20)$ & $(20)$ & $(22)$ & $(21)$ \\
344 & 288 & 206 & 382 \\
$(26)$ & $(26)$ & $(26)$ & $(26)$
\end{tabular}

${ }^{2}$ For individuals a and $d$ the length of the cycle was 26 days.

Numbers in parentheses indicate the days in the cycle investigated. $\mathrm{Ov}=$ ovulation day.

fourth, $3 \%$. The variations were therefore relatively small, and there was no common pattern in the differences; only in two individuals was the greatest serum activity during the proliferative phase of the cycle.

PREGNANCY Table VII indicates that the serum $\beta$-glucuronidase level increases during at least the later stages of pregnancy. These few investigations are in agreement with the results presented by McDonald and Odell (1947).

EFFECT OF DIALYSIS OR DILUTION OF THE SERUM In the majority of dialysed sera the activity was enhanced, presumably because dialysible inhibitors were removed. Dilution of serum before assay also results in a proportionally greater activity than in the original serum. When dialysed serum was diluted the relative activity was increased, indicating the presence of undialysible inhibitors.

ENZYME ACTIVITY IN BLOOD CELLS Fishman et al. (1948) have reported on $\beta$-glucuronidase in blood 
TABLE VII

SERUM $\beta$-GLUCURONIDASE LEVELS IN PREGNANT WOMEN

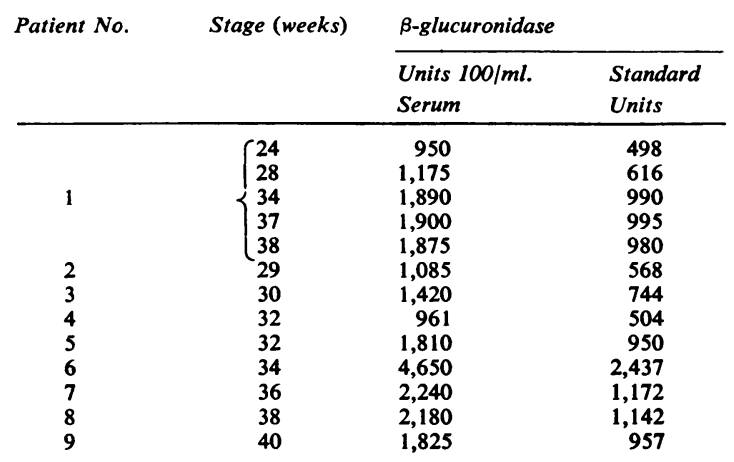

cells where it appears to be concentrated in the leucocytes. The possibility that errors might arise in serum determination due to lysis of the cells has been examined. It has been demonstrated that when whole blood was stored at $4^{\circ} \mathrm{C}$. for 24 hours before removal of the serum the serum enzyme value was only $\pm 6 \%$ different from the value in serum immediately separated from the cells. In experiments where red cells and the buffy coat were separated, laked, and estimated, the finding of Fishman et al. (1948) that red cells contained little or no enzyme activity although the buffy coat had a large enzyme concentration was corroborated.

I wish to thank Dr. F. J. W. Lewis for encouragement and advice, and Professor G. Gordon Lennon for laboratory facilities. I should also like to thank members of the hospital staff for cooperation in various ways. The work was supported by a British Empire Cancer Campaign grant and the Ethel Showering grant.

\section{REFERENCES}

Abul-Fadl, M. A. M. (1957). J. clin. Path., 10, 387.

Cohen, S. L., and Huseby, R. A. (1951). Cancer Res., 11, 52.

Fishman, W. H., Kasdon, S. C., Bonner, C. D., Fishman, L. W., and Homburger, F. (1951). J. clin. Endocr., 11, 1425.

, Springer, B., and Brunetti, R. (1948). J. biol. Chem., 173, 449.

Follette, J. H., Valentine, W. N., and Lawrence, J. S. (1952). J. Lab. clin. Med., 40, 825.

Goldbarg, J. A , Pineda, E. P., Banks, B. M., and Rutenburg, A. M. (1959). Gastroenterology, 36, 193.

Goldstein, G. (1961). Proc. 4th Int. Congr. clin. Chem. Edinb., 1960, p. 183. Butterworth, London.

Hackensellner, H. A., Seelich, F., and Lind, H. (1958). Wien. klin. Wschr., 70, 28.

Lineweaver, H., and Burk, D. (1934). J. Amer. chem. Soc., 56, 658. McDonald, D. F., and Odell, L. D. (1947). J. clin. Endocr., 7, 535.

Mattea, E., Pietra, E., and Viola, M. R. (1959). Tumori, 45, 391.

Ohkubo, T., Sonoda, T., and Kusunoki, T. (1958). Urol. int. (Basel), $7,167$.

Pineda, E. P., Goldbarg, J. A., Banks, B. M., and Rutenburg, A. M. (1959). Gastroenterology, 36, 202.

Talalay, P., Fishman, W. H., and Huggins, C. (1946). J. biol. Chem., $166,757$.

Whitaker, B. L. (1960). Brit. J. Cancer, 14, 471. 